\title{
MEMBANGUN NIAT BELI IPHONE MELALUI EWOM DAN BRAND
} IMAGE

\author{
Rizky Darmawan ${ }^{1}$ \\ I Nyoman Nurcaya ${ }^{2}$ \\ ${ }^{1,2}$ Fakultas Ekonomi dan Bisnis Universitas Udayana (Unud), Bali, Indonesia \\ e-mail: rdarmawan576@gmail.com
}

\begin{abstract}
ABSTRAK
Niat beli merupakan niat seseorang dalam suatu proses pembelian, apakah orang tersebut berniat membeli produk atau tidak. Tujuan dari penelitian ini adalah untuk mengetahui pengaruh EWOM terhadap brand image, pengaruh EWOM terhadap niat beli, pengaruh brand image terhadap niat beli serta peran brand image dalam memediasi hubungan EWOM dengan niat beli produk Iphone. Populasi dalam penelitian ini adalah warga Kota Denpasar yang berniat membeli produk Iphone. Penentuan sampel dalam penelitian ini memakai teknik purposive sampling. Jumlah sampel yang diambil sebanyak 110 orang. Teknik analisis yang dipakai yaitu teknik analisis jalur atau path analysis dan Uji Sobel. Temuan penelitian ini menunjukkan bahwa terdapat hubungan yang positif dan signifikan antara EWOM dengan brand image, EWOM dengan niat beli, brand image dengan niat beli. Brand image dapat berperan sebagai variabel mediasi antara pengaruh EWOM dengan niat beli. Hasil tersebut menandakan bahwa EWOM yang positif dapat meningkatkan brand image serta mampu meningkatkan niat beli konsumen terhadap produk Iphone.
\end{abstract}

Kata Kunci : brand image, EWOM, niat beli

\begin{abstract}
Intention to buy is the intention of someone in a buying process, whether the person intends to buy the product or not. The purpose of this research is to know the effect of EWOM on brand image, EWOM influence to purchase intention, influence of brand image to purchase intention and brand image role in mediating EWOM relationship with intention to buy Iphone product. The population in this study is the citizens of Denpasar who intend to buy Iphone products. Determination of the sample in this study using purposive sampling technique. The number of samples taken as many as 110 people. Analysis technique used is path analysis technique or path analysis and Sobel Test. The findings of this study indicate that there is a positive and significant relationship between EWOM with brand image, EWOM with the intention to buy, brand image with the intention to buy. Brand image can act as a mediating variable between EWOM influence with purchase intention. These results indicate that a positive EWOM can improve the brand image and can increase consumer purchase intentions towards Iphone products.
\end{abstract}

Keywords: brand image, EWOM, purchase intention 


\section{PENDAHULUAN}

Kemajuan teknologi di era global ini membuat konsumen memperoleh kemudahan dalam berbagai hal, misalnya dengan menggunakan handphone konsumen tidak hanya sekedar berkomunikasi tetapi juga dapat berbelanja dengan mudah melalui Internet sesuai dengan kebutuhannya. Indonesia termasuk negara yang memiliki penduduk terpadat di dunia (Central Intelligence Agency World Factbook Tahun 2016) tentunya hal tersebut berdampak pada tingginya minat pemakaian Internet di Indonesia, hal ini dibuktikan oleh Tabel 1 yaitu sebagai berikut :

\section{Tabel 1.}

Empat (4) Negara Dengan Pengguna Internet Tertinggi

\begin{tabular}{clccc}
\hline Ranking & Negara & $\mathbf{2 0 1 4}(\boldsymbol{\%})$ & $\begin{array}{c}\text { Tahun } \\
\mathbf{2 0 1 5}(\boldsymbol{\%})\end{array}$ & $\mathbf{2 0 1 6 ( \% )}$ \\
\hline 1 & China & 643.6 & 669.8 & 700.1 \\
2 & USA & 252.9 & 259.3 & 264.9 \\
3 & Jepang & 102.1 & 103.6 & 104.5 \\
4 & Indonesia & 83.7 & 93.4 & 102.8 \\
\hline
\end{tabular}

Sumber: Data diolah, 2018

Angka tersebut menunjukkan bahwa besarnya minat masyarakat terhadap kemajuan teknologi yang tentunya berbasis Internet. Seiring dengan kemajuan jaman fungsi sebuah handphone tidak hanya sekedar sebagai alat komunikasi, tetapi sudah menjadi kebutuhan penting bagi masyarakat. Perubahan fungsi sebuah handphone menuntut produsen untuk merancang dan menciptakan handphone pintar atau yang disebut dengan smartphone, produsen berkompetisi untuk menciptakan smartphone yang canggih dengan fitur-fitur terbaik untuk memenuhi kebutuhan konsumen, sehingga konsumen diberikan berbagai macam pilihan smartphone dengan merek dan spesifikasi yang berbeda - beda. 
Rizky Darmawan, Peran Brand Image dalam Memediasi...

Setiap produsen smartphone menawarkan keunggulan tersendiri sehingga tidak dapat dipungkiri masing-masing produsen memiliki strategi yang berbedabeda untuk meningkatkan angka penjualannya. Shahrinaz et al. (2016) menyatakan bahwa EWOM adalah pernyataan positif atau negatif yang dibuat secara aktual oleh konsumen mengenai produk atau perusahaan yang dibuat untuk melayani konsumen melalui internet. Word of mouth merupakan pendorong utama dalam membentuk sikap konsumen serta mengarahkannya kepada niat perilaku seseorang (Jalilvand \& Samiei 2012). Menurut Jalilvand dan Samiei (2012) dengan teknologi yang semakin maju, sebagian besar pengguna melakukan browsing melalui Internet untuk menggali informasi tentang produk atau perusahaan dan EWOM telah muncul sebagai hasilnya. EWOM dapat digambarkan sebagai cara komunikasi yang memberikan informasi kepada konsumen tentang penjual, penggunaan produk dan juga layanan melalui teknologi berbasis internet (Torlak et al., 2014). Oleh karena itu EWOM mempengaruhi ulasan produk konsumen dan niat pembelian konsumen (BambuerSachse \& Mangold 2011).

Hubungan positif antara EWOM dengan citra merek dan niat beli didukung oleh hasil penelitian (Charo et al., 2015) yaitu EWOM berdampak positif terhadap opini seseorang dalam jejaring sosial. (Lin et al., 2013) mengungkapkan bahwa keterlibatan produk dan citra merek memiliki efek moderasi dalam hubungan antara EWOM dan niat beli. Penelitian yang dilakukan oleh (Setiawan, 2014) menyatakan bahwa EWOM memiliki efek langsung pada destination image, dan 
efek tidak langsung pada kepuasan dan loyalitas yang dimediasi oleh destination image.

Perkembangan jaman dan kemajuan teknologi yang pesat turut menimbulkan faktor yang menjembatani pengaruh dari EWOM terhadap niat beli konsumen dalam dunia bisnis. Salah satu faktornya adalah brand image, dan brand image itu sendiri merupakan kesan bagi sebuah produk yang dapat melekat dalam ingatan konsumen. Brand image yang baik dikatakan mampu meningkatkan nilai dari suatu produk dan mempengaruhi hasil pemasaran. Brand image dalam penelitian ini berfungsi sebagai variabel mediasi antara EWOM terhadap niat beli, apabila terjadi EWOM negatif maka brand image dari sebuah produk juga menjadi negatif sehingga niat beli konsumen menurun, dan sebaliknya jika terjadi EWOM positif maka brand image dari sebuah produk akan meningkat, tentunya dalam hal ini peran brand image menjadi pemediasi sangat penting dikarenakan dapat mengatasi terjadinya EWOM negatif, semakin baik brand image dari sebuah produk maka semakin tinggi pula niat seseorang untuk membeli.

Salah satu produsen smartphone yang memanfaatkan brand image dari produk yang dibuatnya adalah Apple Inc. Salah satu produk andalan dari Apple yaitu Iphone, smartphone canggih yang tentunya dapat membantu para konsumen dalam kegitan sehari-hari. Iphone saat ini mulai dikenal oleh banyak orang, hampir semua kalangan mulai dari remaja hingga dewasa memakai produk Iphone. Pernyataan ini juga didukung melalui Tabel 2 mengenai survey yang 
dilakukan oleh Top brand award tentang delapan produk smartphone yang banyak dibeli pada tahun 2017.

Tabel 2 .

Top Brand Index Delapam (8) Produk Handphone Yang Banyak Dibeli Tahun 2017

\begin{tabular}{cc}
\hline Merek & Top Brand Index \\
\hline Samsung & $46,4 \%$ \\
Nokia & $8,8 \%$ \\
Blackberry & $8,0 \%$ \\
Iphone & $5,1 \%$ \\
Smartfren & $5,1 \%$ \\
Lenovo & $4,4 \%$ \\
Oppo & $4,1 \%$ \\
Huawei & $3,8 \%$ \\
\hline
\end{tabular}

Sumber : Top Brand Award, 2017

Hasil survey yang diperoleh dari Top brand award menunjukkan bahwa Iphone berada pada peringkat 4 dengan perolehan Top brand index sebesar 5,1 persen dan mampu bersaing dengan produk-produk smartphone lainnya, dengan hal tersebut Apple Inc. tentunya terus melakukan inovasi terhadap produk Iphone agar dapat bertahan dipasar dan menarik minat konsumen untuk membeli produk Iphone. Antusias dari konsumen mengenai produk Iphone tidak hanya terjadi di kota besar saja, untuk Provinsi Bali khususnya di kota Denpasar terdapat pusatpusat pemerintahan dan juga kampus yang tentunya tidak asing dengan adanya teknologi, serta masyarakat diperkotaan juga memiliki penghasilan yang tinggi sehingga banyak para konsumen ataupun masyarakat yang ingin membeli produk Iphone terutama dikalangan remaja. Para remaja yang mengenal dunia teknologi dan selalu ingin tampil keren, akan lebih gengsi dan percaya diri apabila mereka memakai produk Iphone, karena produk Iphone memiliki brand image yang sangat kuat. Berdasarkan pra survey yang sebelumnya telah dilakukan pada hari Rabu 27 Juli 2017 di kota Denpasar mengenai niat beli produk Iphone, dari 20 
remaja di kota Denpasar hampir 80 persennya berniat untuk membeli produk Iphone.

Fenomena EWOM yang dimediasi oleh brand image dari produk Iphone diasumsikan memiliki peran yang signifikan dalam mempengaruhi timbulnya niat beli konsumen terhadap produk Iphone. Penelitian ini didasarkan atas penemuan penelitian terdahulu yang berkaitan dengan electronic word of mouth, brand image, dan niat beli dengan hasil penemuan yang berbeda - beda. Berdasarkan research gap tersebut penelitian ini dimaksudkan untuk pengembangan studi dari penelitian - penelitian yang telah dilakukan sebelumnya dan atas penjelasan latar belakang masalah, maka tujuan penelitian ini adalah untuk menjelaskan pengaruh EWOM terhadap brand image pada produk Iphone, untuk menjelaskan pengaruh EWOM terhadap niat beli pada produk Iphone, untuk menjelaskan pengaruh brand image terhadap niat beli produk Iphone, dan untuk menjelaskan peran brand image dalam memediasi EWOM terhadap niat beli produk Iphone.

EWOM dapat digambarkan sebagai cara komunikasi yang memberikan informasi kepada konsumen tentang penjualan dan penggunaan produk dan juga layanan melalui teknologi berbasis internet (Torlak et al., 2014). Menurut LoveLock et al. (2010) word of mouth positif adalah suatu hal yang sangat penting bagi perusahaan jasa, dimana perusahaan jasa biasanya mempunyai kepercayaan dan pengalaman yang tinggi sehingga hal tersebut diasosiasikan dengan resiko yang tinggi pula oleh calon pembeli. 
Rizky Darmawan, Peran Brand Image dalam Memediasi...

Penelitian yang dilakukan Honorata dan Denny (2015) menyebutkan bahwa terdapat hubungan antara pengalaman baik yang positif dari pemakaian suatu produk barang atau jasa dengan kepuasan konsumen, yang akhirnya dapat mendorong WOM menjadi positif. Honorata dan Denny (2015) mengungkapkan bahwa ada empat hal yang membuat seseorang terlibat dalam WOM positif, yakni pertama, product involvement, yang menyebabkan ketegangan, sehingga untuk mengurangi ketegangannya, perlu diadakan pem-bicaraan mengenai produk tersebut. Kedua, self enhancement, WOM muncul karena seseorang ingin memenuhi kebutuhan emosional tertentu. Ketiga, adanya message involvement, karena adanya iklan atau informasi yang unik sehingga konsumen ingin membicarakannya dengan orang lain. Keempat, other involvement, muncul karena ingin membantu orang lain. Penelitian yang dilakukan Jalilvand dan Samiei (2012), serta Torlak et al. (2014) menunjukkan bahwa adanya hubungan positif yang signifikan antara EWOM, terhadap brand image. Berdasarkan telaah dan kajian penelitian terdahulu, maka dapat disusun hipotesis sebagai berikut: EWOM berpengaruh positif dan signifikan terhadap brand image.

Internet menciptakan sebuah paradigma baru dalam komunikasi word of mouth dan inilah awal munculnya istilah EWOM. Fenomena EWOM dianggap sebagai perkembangan dari komunikasi tradisional interpersonal menuju generasi baru dari cyberspace (Hatane dan Adi 2014). Penelitian yang dilakukan Honorata dan Denny (2015) menyebutkan bahwa terdapat hubungan antara pengalaman baik yang positif dari pemakaian suatu produk barang atau jasa dengan kepuasan konsumen, yang akhirnya dapat mendorong word of mouth menjadi positif. Honorata 
dan Denny (2015) mengungkapkan bahwa ada empat hal yang membuat seseorang terlibat dalam WOM positif, yakni pertama, product involvement, yang menyebabkan ketegangan, sehingga untuk mengurangi ketegangannya, perlu diadakan pem-bicaraan mengenai produk tersebut. Kedua, self enhancement, WOM muncul karena seseorang ingin memenuhi kebutuhan emosional tertentu. Ketiga, adanya message involvement, karena adanya iklan atau informasi yang unik sehingga konsumen ingin membicarakannya dengan orang lain. Keempat, other involvement, muncul karena ingin membantu orang lain. Penelitian lain yang dilakukan oleh Honorata dan Dwi (2015), Sweeney (2012) serta Bataineh (2015) mengungkapkan bahwa EWOM berpengaruh secara positif terhadap purchase intention. Berdasarkan telaah dan kajian penelitian terdahulu, maka dapat disusun hipotesis sebagai berikut: EWOM berpengaruh positif dan signifikan terhadap niat beli konsumen.

Citra merek itu melibatkan komunikasi fitur eksternal produk yang signifikan kepada konsumen. Ketika konsumen ingin membeli produk, konsumen mengekspresikan asosiasi merek dan kesadaran yang merangsang perilaku pembelian mereka (Chao et al., 2016). Penelitian sebelumnya yang dilakukan (Ambarwati dkk., 2015) menyatakan apabila citra merek meningkat maka minat beli seseorang terhadap produk pepsodent juga meningkat. Penelitian yang dilakukan oleh (Wibowo, 2015), (Torlak et al., 2014) menunjukkan bahwa brand image berpengaruh positif terhadap purchase intention. Berdasarkan telaah dan 
kajian penelitian terdahulu, maka dapat disusun hipotesis sebagai berikut: brand image berpengaruh positf dan signifikan terhadap niat beli konsumen.

Dengan adanya brand image yang kuat, dapat dipakai oleh seorang pemasar untuk mendorong konsumen agar memiliki keinginan untuk membeli. Niat pembelian yang timbul dari dalam diri konsumen sangat identik dengan brand image yang positif (Wijaya \& Sugiono 2015).

Berdasarkan penelusuran kajian pustaka dan hasil-hasil penelitian terdahulu. Maka model penelitian dalam penelitian ini adalah sebagai berikut.

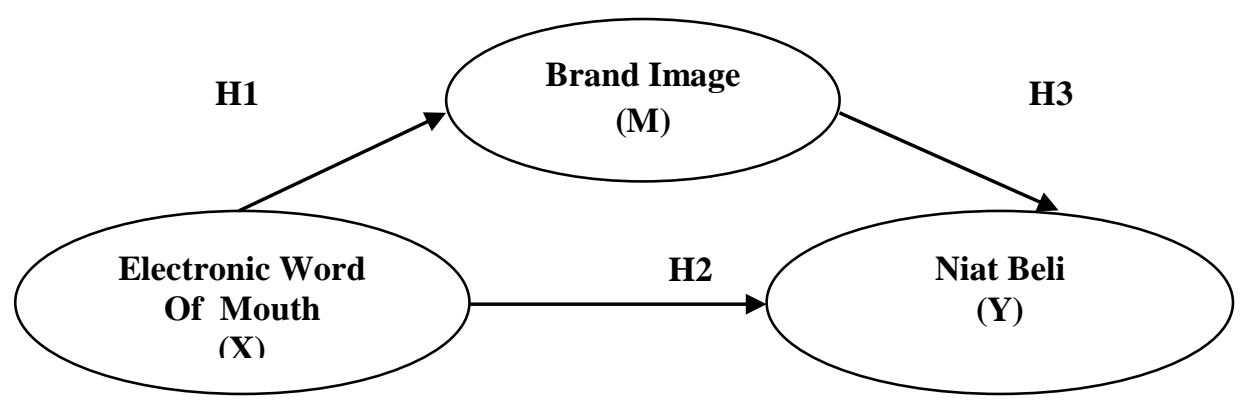

\section{Gambar 1. Model Penelitian}

Sumber : Jalilvand dan Samiei (2012)

Penelitian terdahulu yang dilakukan oleh Shukla dalam (Jalilvand dan Samiei, 2012) menunjukkan bahwa pengaruh interpersonal dan bentuk isyarat dari branding berkaitan dengan niat membeli yang mewah dari konsumen, hasil studinya menunjukkan bahwa pengaruh interpersonal normatif ditemukan signifikan di seluruh negara, dan peran interpersonal informasi sangat penting di kalangan konsumen, bahkan citra merek adalah moderator yang signifikan antara pengaruh interpersonal normatif dan juga niat membeli yang mewah. Berdasarkan telaah dan kajian penelitian terdahulu, maka dapat disusun hipotesis sebagai berikut: brand image memediasi EWOM terhadap niat beli konsumen. 


\section{METODE PENELITIAN}

Penelitian ini menguji hipotesis yang menjelaskan pengaruh EWOM terhadap brand image, pengaruh EWOM terhadap niat beli, pengaruh brand image terhadap niat beli, serta peran brand image dalam memediasi hubungan antara EWOM terhadap niat beli. Penelitian ini dilakukan pada konsumen yang belum memakai atau ingin memakai produk Iphone di kota Denpasar. Lokasi ini dipilih karena kota Denpasar merupakan pusat perekonomian di Bali, selain itu memudahkan bagi peneliti untuk melakukan penelitian dikarenakan banyak terdapat sekolah, kampus - kampus dan juga perkantoran. Populasi dalam penelitian ini adalah para konsumen yang belum memakai produk Iphone ataupun yang berniat membeli produk Iphone di kota Denpasar. Penentuan sampel dalam penelitian ini memakai metode non probability sampling yaitu sebuah teknik pengambilan sampel yang tidak memberikan kesempatan yang sama bagi setiap unsur atau anggota dalam populasi untuk dipilih menjadi sampel (Rahyuda dkk., 2004). Teknik non probability sampling yang dipilih adalah purposive sampling yaitu teknik penentuan sampel dengan kriteria tertentu. Adapun kriteria dari penentuan sampel dalam penelitian ini adalah responden memiliki tingkat pendidikan minimal SMA/ Sederajat, dengan asumsi bahwa responden dengan tingkat pendidikan minimal SMA dapat memahami dan mampu untuk menjawab kuisioner. Selain itu, responden belum pernah membeli produk Iphone, dan mengetahui informasi mengenai produk Iphone. 
Rizky Darmawan, Peran Brand Image dalam Memediasi...

Masing- masing variabel atau indikator penelitian didefinisikan sebagai berikut :

Tabel 3.

Indikator Variabel Penelitian

\begin{tabular}{|c|c|c|c|c|}
\hline No & Klasifikasi & Konstruk & Indikator & Sumber \\
\hline 1 & Endogen & $\begin{array}{l}\text { Niat } \\
\text { Beli }\end{array}$ & $\begin{array}{l}\text { 1) Kesediaan konsumen yang akan } \\
\text { melakukan pembelian. (Y.1) } \\
\text { 2) Keinginan konsumen untuk } \\
\text { melakukan pembelian di masa depan. } \\
\text { (Y.2) } \\
\text { 3) Keinginan konsumen untuk } \\
\text { melakukan pembelian. (Y.3) }\end{array}$ & $\begin{array}{l}\text { (Rahman et al. } \\
\text { 2012) }\end{array}$ \\
\hline 2 & Mediasi & $\begin{array}{l}\text { Brand } \\
\text { Image }\end{array}$ & $\begin{array}{l}\text { 1) Sincerity, dimensi ini meliputi merek } \\
\text { yang dianggap jujur (M.1) } \\
\text { 2) Excitement merek dianggap sebagai } \\
\text { berani, ber-semangat, imajinatif, up } \\
\text { to date, dan inovatif (M.2) } \\
\text { 3) Sophistication yaitu merek yang } \\
\text { dianggap berkelas, mewah, dan } \\
\text { canggih. (M.3) }\end{array}$ & (Shimp 2010) \\
\hline 3 & Eksogen & EWOM & $\begin{array}{l}\text { 1) Membaca ulasan produk dari } \\
\text { konsumen online lainnya. (X.1) } \\
\text { 2) Berdiskusi dengan konsumen online } \\
\text { lainnya. (X.2) } \\
\text { 3) Sering mencari informasi online } \\
\text { sebelum membeli sebuah produk. } \\
\text { (X.3) } \\
\text { 4) Jika tidak membaca ulasan produk } \\
\text { dari sesama konsumen online, tidak } \\
\text { yakin dengan keputusan sendiri. } \\
\text { (X.4) } \\
\text { 5) Ulasan dari sesama konsumen online } \\
\text { membuat percaya diri dalam } \\
\text { membuat keputusan membeli. (X.5) }\end{array}$ & $\begin{array}{l}\text { (Bambauer } \\
\text { Sachse } \\
\text { dan } \\
\text { Mangold } \\
\text { 2011) }\end{array}$ \\
\hline
\end{tabular}

Dalam sebuah penelitian untuk memperoleh suatu data yang valid maka jumlah sampel responden yang diambil dan ditentukan paling sedikitnya 5-10 kali jumlah indikator (Sugiyono. 2013:130). Jumlah dari sampel responden yang akan diuji di dapat dari hasil perhitungan yaitu 11 indikator x 10. Jadi, jumlah responden yang digunakan yaitu sebanyak 110 responden. 
Penelitian ini memakai teknik analisis jalur atau biasa disebut path analysis, untuk menganalisis pola hubungan antar variabel dengan tujuan untuk mengetahui pengaruh langsung ataupun tidak langsung suatu variabel bebas (EWOM) terhadap variabel terikat (Niat Beli), dengan persamaan struktur sebagai berikut :

Substruktur $1: M=\beta 1 X+\varepsilon 1$

Substruktur $2: \mathrm{Y}=\beta 2 \mathrm{X}+\beta 3 \mathrm{M}+\varepsilon 2$

Keterangan :

$$
\begin{aligned}
& \mathrm{Y}=\text { Niat Beli } \\
& \mathrm{M}=\text { Brand Image } \\
& \mathrm{X}=\mathrm{EWOM} \\
& \beta 1, \beta 2, \beta 3=\text { koefisien regresi variabel } \\
& \mathrm{e}=\text { error }
\end{aligned}
$$

Pengujian Hipotesis Mediasi dalam penelitian ini menggunakan uji Sobel atau biasa disebut dengan Sobel test. Uji sobel atau Sobel test dipakai untuk menguji seberapa kekuatan pengaruh langsung antara variabel EWOM (X) ke variabel niat beli produk Iphone (Y) melalui variabel brand image (M). Pengaruh tidak langsung EWOM (X) terhadap variabel niat beli (Y) melalui variabel brand image $(\mathrm{M})$ dihitung dengan cara mengalikan antara koefisien jalur $\mathrm{X}$ terhadap $\mathrm{M}$ (a) dengan koefisien jalur M terhadap Y (b) atau ab. Standard error dari koefisien a dan $b$ nantinya ditulis dengan huruf atau symbol $S_{a}$ dan $S_{b}$, dan besarnya standard error tidak langsung (indirect effect) $\mathrm{S}_{\mathrm{ab}}$. Uji sobel dihitung memakai rumus dibawah ini:

$$
Z=\frac{a b}{\sqrt{b^{2} s_{a}^{2}+a^{2} s_{b}^{2}+s_{a}^{2} s_{b}^{2}}}
$$


$\operatorname{Sig}=(1-\operatorname{NORMDIST}(Z))+2)$

Keterangan:

$\mathrm{a}=$ koefisien regresi dari variabel bebas $(\mathrm{X})$ terhadap variabel mediasi (M)

$\mathrm{s}_{\mathrm{a}}=$ standard eror dari $\mathrm{a}$

$\mathrm{b}=$ koefisien regresi dari variabel mediasi terhadap variabel dependen (Y)

$\mathrm{s}_{\mathrm{b}}=$ standard eror dari $\mathrm{b}$

\section{HASIL DAN PEMBAHASAN}

Penelitian ini memakai 110 orang responden dimana hal ini sesuai dengan penentuan ukuran sampel yang digunakan. Penjelasan mengenai responden dalam penelitian ini akan dijelaskan dengan karakteristik demografi responden yang terdiri dari jenis kelamin, usia, tingkat pendidikan, serta pekerjaan tersaji pada Tabel 4

Berdasarkan data pada Tabel 4 terlihat bahwa presentase untuk jenis kelamin laki - laki dan perempuan memiliki kesamaan yaitu sebesar 50 persen, hal ini menandakan bahwa laki - laki ataupun perempuan memiliki minat beli yang sama terhadap produk Iphone. Selanjutnya untuk usia responden mayoritas berusia 17 sampai 21 tahun dengan presentase sebesar 70,9 persen. Hal ini menandakan bahwa pada usia 17 sampai 21 tahun banyak para konsumen yang tertarik untuk membeli dan menggunakan produk Iphone, disamping itu pada usia 17 sampai 21 tahun kebanyakan konsumen mementingkan gaya hidup atau lifestyle untuk menunjukkan jati dirinya. 
Tabel 4.

Karakteristik Responden

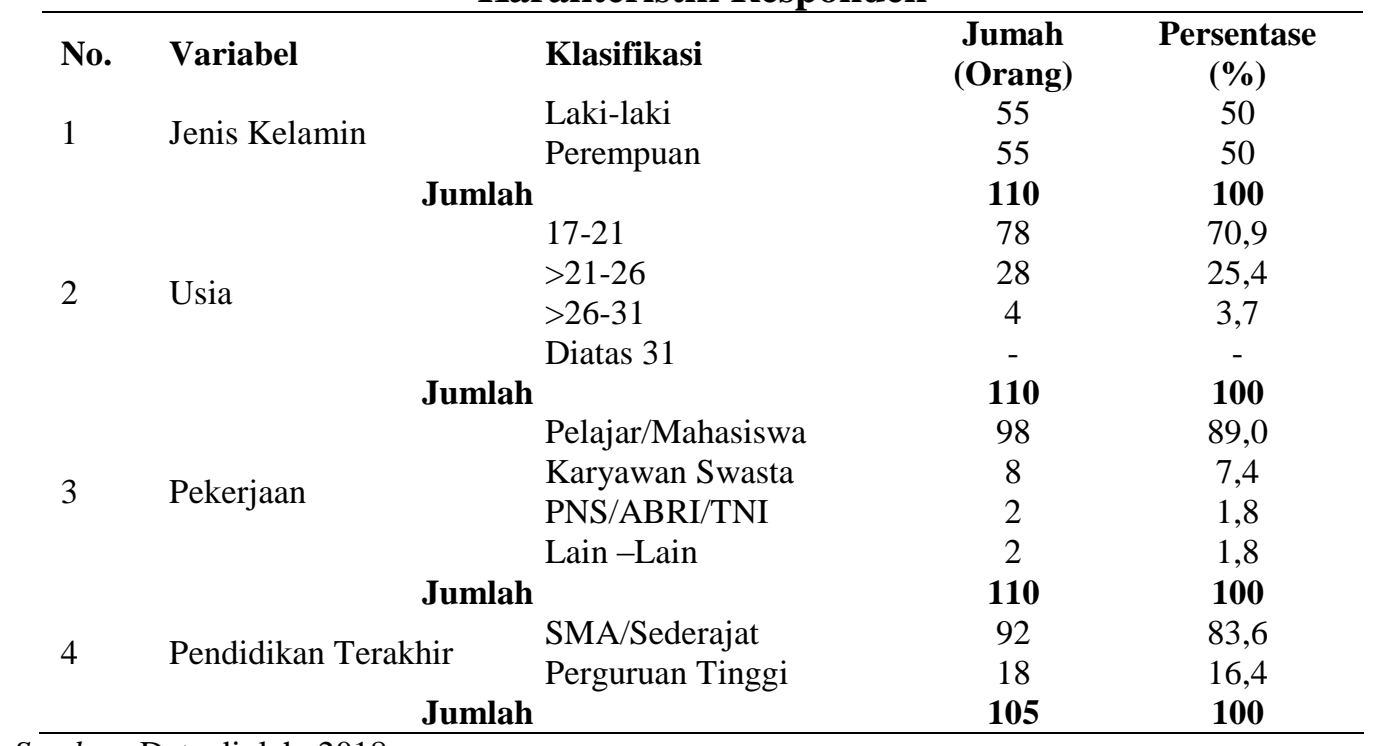

Sumber: Data diolah, 2018

Klasifikasi berikutnya yaitu pekerjaan, dimana pada klasifikasi pekerjaan didominasi oleh pelajar / mahasiswa dengan presentase 89,0 persen. Hal ini menunjukkan bahwa sebagian besar dikalangan pelajar / mahasiswa memerlukan smartphone yang canggih dan mewah guna mendukung kegiatan sehari - hari dan gaya hidup pelajar / mahasiswa itu sendiri. Klasifikasi terakhir yaitu pendidikan terakhir, untuk klasifikasi pendidikan terakhir SMA / sederajat mendominasi dengan presentase sebesar 83,6 persen.

Hasil uji validitas pada penelitian ini menunjukkan bahwa 11 indikator yang dipakai dalam penelitian memiliki nilai korelasi lebih besar dari 0,3 sehingga keseluruhan indikator yang dipakai dinyatakan valid. Kemudian Hasil uji reliabilitas instrumen penelitian ini juga menunjukkan nilai cronbach alpha lebih besar dari 0,60 sehingga seluruh indikator yang digunakan dalam penelitian ini dikatakan reliabel. 
Rizky Darmawan, Peran Brand Image dalam Memediasi...

Apabila disesuaikan dengan interval kelas dalam deskripsi variabel penelitian, maka indikator - indikator yang dipakai dalam variabel EWOM tergolong dalam rentang cukup baik hingga baik yang berarti responden sering melakukan kegiatan yang disebutkan dalam indikator, seperti membaca ulasan produk, mencari informasi mengenai produk Iphone, serta berdiskusi dengan sesama konsumen online mengenai produk Iphone.

Tabel 5.

Deskripsi Jawaban Responden Terhadap Variabel EWOM

\begin{tabular}{|c|c|c|c|c|c|c|c|}
\hline \multirow{2}{*}{ Pernyataan } & \multicolumn{5}{|c|}{ Skor Jawaban } & \multirow{2}{*}{$\begin{array}{l}\text { Jumlah } \\
\text { Skor }\end{array}$} & \multirow{2}{*}{$\begin{array}{l}\text { Rata- } \\
\text { rata }\end{array}$} \\
\hline & 1 & 2 & 3 & 4 & 5 & & \\
\hline $\begin{array}{l}\text { Saya pernah membaca mengenai } \\
\text { ulasan produk iphone dari konsumen } \\
\text { melalui media internet / online. }\end{array}$ & 0 & 2 & 9 & 61 & 38 & 465 & 4,23 \\
\hline $\begin{array}{l}\text { Saya pernah berdiskusi membahas } \\
\text { produk iphone dengan sesama } \\
\text { pengguna media internet. }\end{array}$ & 1 & 4 & 14 & 61 & 30 & 445 & 4,05 \\
\hline $\begin{array}{l}\text { Saya sering mencari informasi } \\
\text { melalui media internet / online } \\
\text { mengenai produk iphone. }\end{array}$ & 0 & 2 & 16 & 49 & 43 & 463 & 4,21 \\
\hline $\begin{array}{l}\text { Saya merasa tidak yakin dengan } \\
\text { keputusan sendiri apabila tidak } \\
\text { membaca ulasan produk iphone dari } \\
\text { sesama pengguna media internet. }\end{array}$ & 0 & 5 & 26 & 50 & 29 & 433 & 3,94 \\
\hline $\begin{array}{l}\text { Saya merasa percaya diri dalam } \\
\text { membuat keputusan untuk membeli } \\
\text { produk iphone, apabila saya } \\
\text { membaca ulasan dari sesama } \\
\text { pengguna media internet. }\end{array}$ & 0 & 4 & 18 & 55 & 33 & 447 & 4,06 \\
\hline Total & & & & & & 2253 & 4,10 \\
\hline
\end{tabular}

Sumber : data diolah, 2018

Tabel 5 menunjukkan responden rata - rata menjawab setuju, ini menandakan bahwa variabel EWOM salah satu faktor penting bagi konsumen dalam penentuan niat beli produk Iphone. Indikator "Saya pernah membaca mengenai ulasan produk Iphone dari konsumen melalui media Internet / online” memberikan dampak paling besar bagi variabel EWOM dengan rata - rata skor 
sebesar 4,23 hal tersebut menandakan bahwa konsumen sebelum berniat untuk membeli produk Iphone, mereka lebih dahulu membaca review atau ulasan dari para pengguna internet mengenai produk Iphone.

Variabel brand image merupakan variabel mediasi dalam penelitian ini, dan menggunakan 3 indikator. Dapat dilihat pada Tabel 6 mengenai hasil deskripsi jawaban responden terhadap variabel brand image.

Tabel 6.

Deskripsi Jawaban Responden Terhadap Variabel Brand Image

\begin{tabular}{|c|c|c|c|c|c|c|c|c|}
\hline \multirow{2}{*}{ No } & \multirow{2}{*}{ Pernyataan } & \multicolumn{5}{|c|}{ Skor Jawaban } & \multirow{2}{*}{$\begin{array}{l}\text { Jumlah } \\
\text { Skor }\end{array}$} & \multirow{2}{*}{$\begin{array}{c}\text { Rata- } \\
\text { rata }\end{array}$} \\
\hline & & 1 & 2 & 3 & 4 & 5 & & \\
\hline \multirow[t]{3}{*}{1} & Saya merasa bahwa produk & & & & & & & \\
\hline & $\begin{array}{l}\text { Iphone memberikan sistem } \\
\text { keamanan yang lebih baik }\end{array}$ & 0 & 3 & 10 & 49 & 48 & 472 & 4,29 \\
\hline & dibandingkan smatphone lainnya. & & & & & & & \\
\hline \multirow[t]{2}{*}{2} & Saya merasa bahwa produk & & & & & & & \\
\hline & $\begin{array}{l}\text { Iphone selalu melakukan inovasi } \\
\text { terbaru. }\end{array}$ & 0 & 3 & 23 & 41 & 43 & 454 & 4,13 \\
\hline \multirow[t]{3}{*}{3} & Saya merasa bahwa produk & & & & & & & \\
\hline & $\begin{array}{l}\text { Iphone, merupakan salah satu } \\
\text { smartphone yang dianggap } \\
\text { canggih. }\end{array}$ & 0 & 1 & 11 & 49 & 49 & 476 & 4,33 \\
\hline & Total & & & & & & 1402 & 4,25 \\
\hline
\end{tabular}

Sumber : data diolah, 2018

Apabila disesuaikan dengan interval kelas dalam deskripsi variabel penelitian, maka indikator - indikator yang dipakai dalam variabel brand image tergolong dalam rentang yang cukup baik hingga baik yang berarti responden menyadari bahwa indikator dari variabel brand image sesuai dengan produk Iphone dimana indikator tersebut memberikan penjelasan mengenai produk Iphone sebagai salah satu smartphone yang dianggap berkelas, mewah dan juga inovatif, selain itu untuk jawaban responden rata - rata menjawab setuju, ini menandakan bahwa variabel brand image merupakan faktor penting bagi 
Rizky Darmawan, Peran Brand Image dalam Memediasi...

konsumen dalam penentuan niat beli produk Iphone. Indikator "Saya merasa bahwa produk Iphone, merupakan salah satu smartphone yang dianggap canggih." memberikan dampak paling besar bagi variabel brand image dengan rata - rata skor sebesar 4,33 hal tersebut menandakan bahwa konsumen berniat untuk membeli produk Iphone dikarenakan Iphone merupakan merek yang dianggap berkelas dan mewah, sehingga meningkatkan rasa percaya diri bagi pemakai produk Iphone itu sendiri.

Variabel niat beli merupakan variabel terikat dalam penelitian ini, dan menggunakan 3 indikator. Dapat dilihat pada Tabel 7 mengenai hasil deskripsi jawaban responden terhadap variabel niat beli.

Tabel 7.

Deskripsi Jawaban Responden Terhadap Variabel Niat Beli

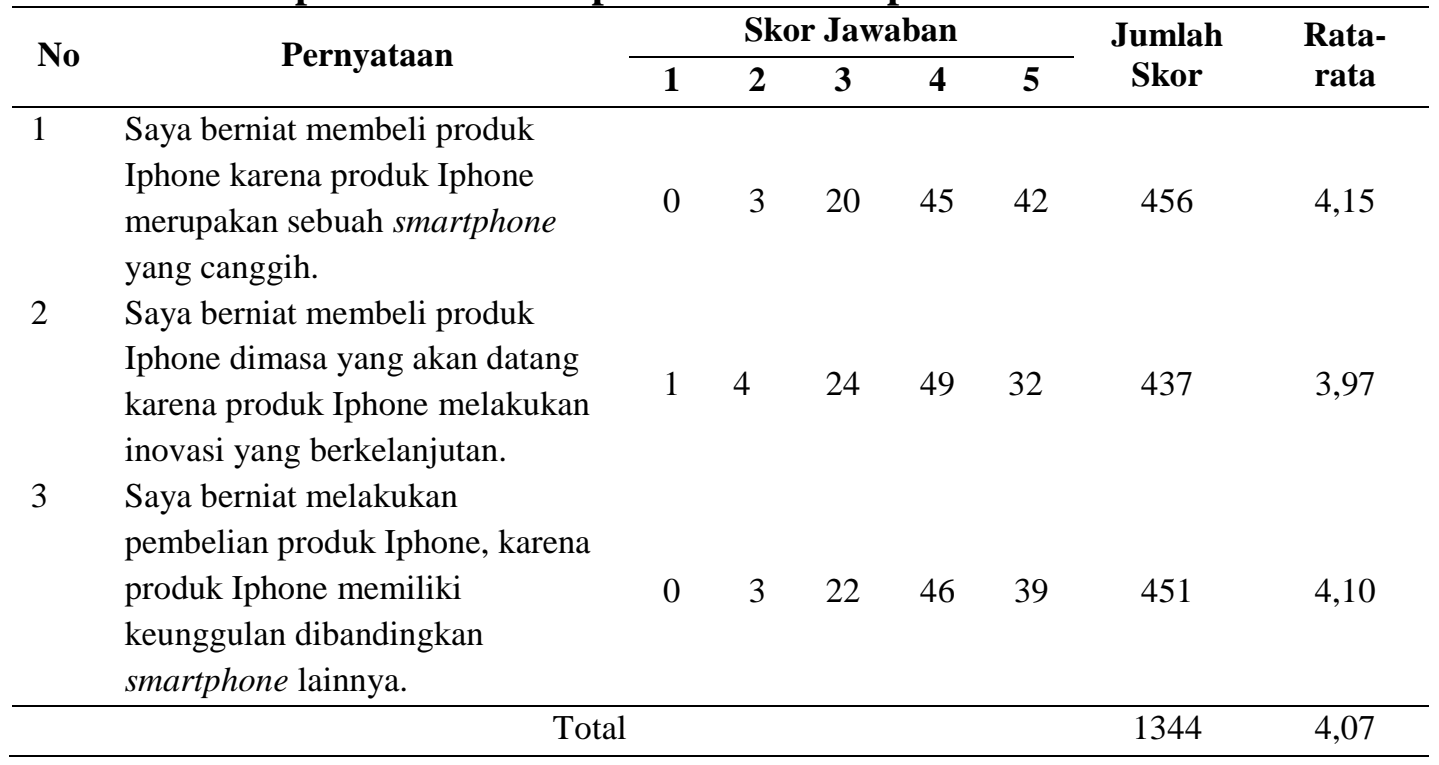

Sumber : data diolah, 2018

Apabila disesuaikan dengan interval kelas dalam deskripsi variabel penelitian, maka indikator - indikator yang dipakai dalam variabel niat beli tergolong dalam rentang yang cukup baik hingga baik yang berarti indikator 
dalam variabel niat beli mampu mendeskripsikan keinginan konsumen untuk membeli produk Iphone, selain itu untuk jawaban responden rata - rata menjawab setuju, ini menandakan bahwa niat beli konsumen untuk produk Iphone sangat tinggi. Indikator "Saya berniat membeli produk Iphone karena produk Iphone merupakan sebuah smartphone yang canggih." memberikan dampak paling besar bagi variabel niat beli dengan rata - rata skor sebesar 4,15 hal tersebut menandakan bahwa konsumen memiliki minat yang tinggi terhadap produk Iphone dan bersedia untuk membeli produk Iphone.

Persamaan struktur I dalam penelitian ini, dapat disusun berdasarkan hasil pelaporan analisis regresi I sebagai berikut :

$$
\begin{aligned}
& \mathrm{M}=0,605 \mathrm{X} \\
& \mathrm{Se}=0,050 \\
& \mathrm{t}=7,900 \\
& \text { Sig } \mathrm{F}=0,000 \\
& \mathrm{R}^{2}=0,366 \\
& \mathrm{~F} \quad=62,418
\end{aligned}
$$

Dari pelaporan regresi I dapat ditulis persamaan struktur I, yaitu sebagai berikut :

$$
\mathrm{M}=0,605 \mathrm{X}
$$

Persamaan struktural II dalam penelitian ini, didapat dari hasil analisis regresi II, yang dilaporkan sebagai berikut :

$$
\begin{aligned}
& \mathrm{Y}=0,258 \mathrm{X}+0,663 \mathrm{M} \\
& \mathrm{Se}=(0,047) \quad(0,071) \\
& \mathrm{t}=(3,958) \quad(10,186) \\
& \text { Sig } \mathrm{F}=0,000 \\
& \mathrm{R}^{2}=0,713 \\
& \mathrm{~F} \quad=132,718
\end{aligned}
$$


Rizky Darmawan, Peran Brand Image dalam Memediasi...

Dari pelaporan regresi II dapat ditulis persamaan struktur II, yaitu sebagai berikut :

$$
\mathrm{Y}=0,258 \mathrm{X}+0,663 \mathrm{M}
$$

Berdasarkan model struktur I dan II, dapat disusun model diagram jalur akhir, namun sebelumnya nilai standar error harus dihitung terlebih dahulu. Perhitungan nilai standar error dalam penelitian ini didapatkan hasil pengaruh error $\left(e_{1}\right)$ sebesar 0,796 dan pengaruh error $\left(e_{2}\right)$ sebesar 0,535. Selanjutnya menghitung koefisien determinasi total. Hasil perhitungan koefisien determinasi total didapatkan nilai sebesar 0,819 yang memiliki arti bahwa sebesar 81,9 persen variasi niat beli dipengaruhi oleh EWOM, dan brand image sedangkan sisanya sebesar 18,1 persen dijelaskan oleh faktor lain yang tidak dimasukkan ke dalam model.

Berdasarkan validasi model diagram jalur pada Gambar 2 selanjutnya dapat dihitung besarnya pengaruh langsung, pengaruh tidak langsung kemudian pengaruh total antar variabel dalam penelitian ini, untuk penjelasannya dapat dilihat pada Tabel 8 mengenai rangkuman perhitungan pengaruh antar variabel.

Hasil koefisien jalur pada hipotesis penelitian ini dapat dilihat pada Gambar 2. Hasil yang ditunjukkan pada Tabel 8 menandakan pengaruh langsung variabel EWOM terhadap niat beli mempunyai nilai koefisien sebesar 0,258, sedangkan untuk pengaruh tidak langsung melalui variabel brand image sebagai mediasi menunjukkan nilai koefisien sebesar 0,401 dengan pengaruh total sebesar 0,659 . 


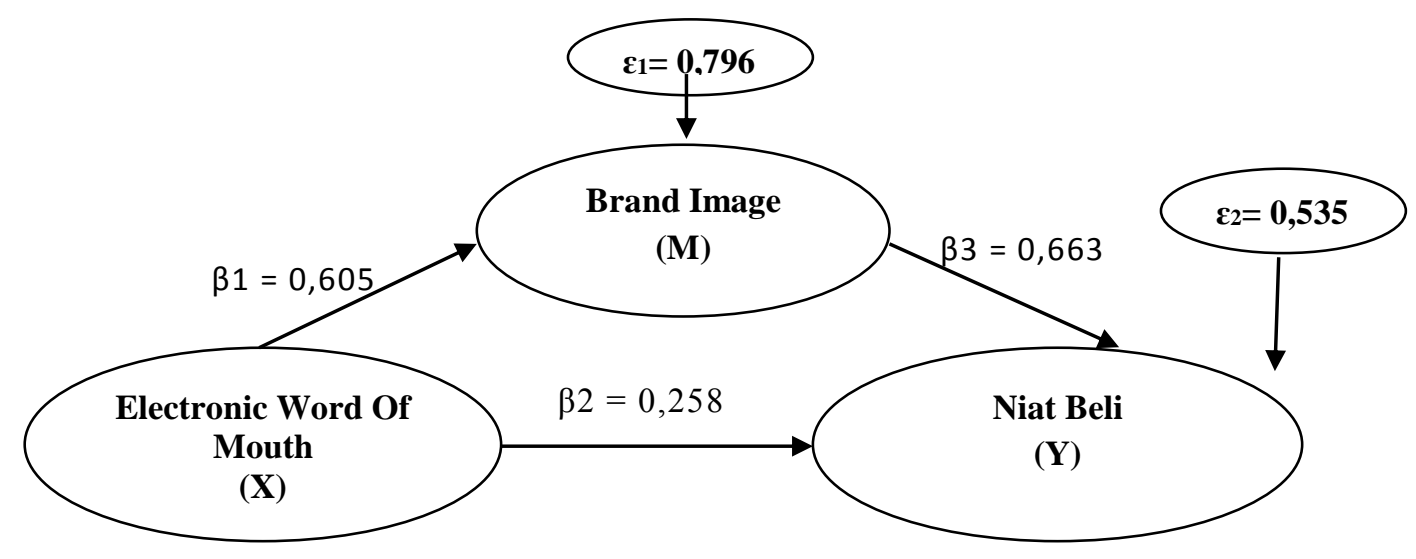

Gambar 2. Validasi Model Diagram Jalur Akhir

Tabel 8.

Pengaruh langsung, Pengaruh Tidak Lamgsung serta Pengaruh Total EWOM (X), Brand Image (M), dan Niat Beli (Y)

\begin{tabular}{lccc}
\hline Pengaruh Variabel & Pengaruh Langsung & $\begin{array}{c}\text { Pengaruh Tidak } \\
\text { Langsung Melalui } \\
\text { Brand Image }(\mathrm{M})\end{array}$ & Pengaruh Total \\
\hline $\mathrm{X} \rightarrow \mathrm{M}$ & 0,605 & - & 0,605 \\
$\mathrm{X} \longrightarrow \mathrm{Y}$ & 0,258 & 0,401 & 0,659 \\
$\mathrm{M} \rightarrow \mathrm{Y}$ & 0,663 & - & 0,663 \\
\hline
\end{tabular}

Sumber : data diolah, 2018

Hasil pengujian menunjukkan bahwa nilai koefisien beta sebesar 0,605 dengan tingkat signifikansi sebesar 0,000 lebih kecil dari 0,05 yang memiliki arti bahwa H1 diterima. Hal ini menandakan bahwa EWOM berpengaruh positif dan signifikan terhadap brand image, dengan demikian berdasarkan latar belakang penelitian, produk Iphone memiliki brand image yang kuat, jadi untuk membuktikan hal tersebut, telah diteliti sejauh mana pengaruh EWOM dalam mempengaruhi brand image dari produk Iphone. Responden yang ikut serta dalam pengisian kuisioner penelitian memiliki tanggapan yang positif mengenai pernyataan yang berkaitan dengan informasi positif yang diperoleh mengenai 
Rizky Darmawan, Peran Brand Image dalam Memediasi...

produk Iphone, maka dapat disimpulkan terjadi fenomena EWOM yang positif mengenai produk Iphone diantara konsumen.

Hasil penelitian ini sesuai dengan penelitian terdahulu yang telah dilakukan oleh Jalilvand dan Samiei (2012), Shahrinaz et al. (2016), Elseidi dan Dina (2016), Charo et al. (2015) yang menyatakan bahwa EWOM berpengaruh secara positif dan signifikan terhadao brand image. Hal tersebut menandakan bahwa EWOM yang positif memberikan dampak yang positif pula terhadap brand image.

Pengaruh lainnya yang diteliti dalam penelitian ini yaitu pengaruh antara variabel EWOM terhadap niat beli. Pengaruh EWOM terhadap niat beli merupakan pengaruh yang bisa dibilang sangat lazim ditemui dalam dunia pemasaran, tetapi pengaruh ini juga perlu diteliti konsistensinya apabila diterapkan pada studi kasus dari produk Iphone, berdasarkan hasil pengujian yang telah dilakukan, didapatkan hasil bahwa pengaruh EWOM terhadap niat beli memperoleh nilai signifikansi sebesar 0,000 lebih kecil dari 0,05 dengan nilai beta sebesar 0,258 sehingga dapat disimpulkan bahwa EWOM berpengaruh secara positif dan signifikan terhadap niat beli.

Hasil ini sekaligus memperkuat penelitian dari Bataineh (2015), Sa'ait et al. (2016), Wibowo (2015), Aditya dan Wardana (2017) yang mengatakan bahwa EWOM merupakan faktor penting dalam niat beli seseorang. Brand image merupakan suatu keunggulan yang dimiliki oleh perusahaan dalam menjual setiap produk ataupun jasanya kepada konsumen. Berkaitan dengan studi pada produk Iphone, produk Iphone dianggap memiliki brand image yang kuat dan memiliki 
peranan besar dalam mempengaruhi minat beli dari konsumen. Anggapan ini dibuktikan melalui hasil pengujian dalam penelitian ini yang menunjukkan bahwa pengaruh brand image terhadap niat beli memiliki nilai signifikanis sebesar 0,000 lebih kecil dari 0,05 dengan nilai beta sebesar 0,663. Hasil tersebut menandakan bahwa brand image memiliki pengaruh yang positif dan signifikan terhadap niat beli produk Iphone.

Hasil ini sekaligus memperkuat hasil penelitian terdahulu yang dilakukan oleh Moksaoka dan Rahyuda (2016), Shah et al. (2012), Chao dan Liao (2016) yang mengatakan bahwa brand image yang kuat akan mempengaruh minat beli konsumen akan sebuah produk atau jasa.

Pengujian pengaruh mediasi dalam penelitian ini dilakukan dengan uji sobel, yang dihitung berdasarkan rumus sebagai berikut:

$$
Z=\frac{\mathrm{ab}}{\sqrt{\mathrm{b}^{2} s_{a}^{2}+a^{2} s_{b}^{2}+s_{a}^{2} s_{b}^{2}}}
$$

Hasi pengujian dalam penelitian ini diperoleh nilai koefisien $\mathrm{Z}$ sebesar 7,582 dengan tingkat signifikansi sebesar 0,000 lebih kecil dari 0,05 yang berarti H1 diterima. Hasil tersebut menunjukkan variabel brand image mediasi secara parsial pengaruh EWOM terhadap niat beli. Hal tersebut memiliki arti EWOM yang positif akan meningkatkan minat beli konsumen, namun sebaliknya EWOM yang negatif akan mengurangi minat beli konsumen maka dari itu dorongan dari brand image sangat penting dalam memediasi pengaruh antara EWOM terhadap niat beli konsumen, agar minat konsumen untuk membeli menjadi meningkat. 
Rizky Darmawan, Peran Brand Image dalam Memediasi...

Hasil penelitian ini sekaligus memperkuat penelitian terdahulu yang telah dilakukan oleh Torlak et al. (2014), Gadhafi (2015), Wijaya dan Sugiharto (2015) yang masing - masing dalam penelitiannya memperoleh hasil yang menunjukkan keterkaitan antara 3 variabel yang diteliti dalam penelitian ini.

Implikasi hasil penelitian ini menekankan pada manfaat nyata dari hasil penelitian ini bagi pihak - pihak yang berkepentingan khususnya bagi perusahaan yang sedang mengembangkan strategi yang tepat dalam memasarkan produk atau jasanya. Berdasarkan hasil penelitian yang diperoleh terdapat beberapa implikasi strategis yaitu sebagai berikut :

Pertama, secara umum EWOM menjadi media bagi perusahaan Apple dalam mempromosikan produk Iphone, dengan memanfaatkan Internet dan media sosial, banyak konsumen yang memberikan pendapat atau ulasannya mengenai produk yang telah mereka gunakan, dan sekaligus memberikan motivasi bagi konsumen lainnya untuk melakukan pembelian. Pernyataan dengan nilai tertinggi yaitu "membaca ulasan produk dari konsumen lainnya" pernyataan tersebut menunjukkan bahwa konsumen lebih mengutamakan membaca pendapat atau ulasan produk dari orang lain terlebih dahulu sebelum melakukan pembelian agar produk yang mereka beli sesuai dengan yang diinginkan.

Kedua, diketahui bahwa produk Iphone memiliki brand image yang sangat kuat, hal ini dapat dilihat dari pernyataan dengan nilai tertinggi yaitu "merek yang dianggap berkelas dan mewah" hal tersebut menandakkan bahwa produk Iphone mampu meningkatkan rasa percaya diri penggunanya, dengan kemewahan dan 
juga berkelas menjadikan produk Iphone berbeda dengan smartphone smartphone lainnya yang beredar dipasaran.

Implikasi ketiga yaitu, variabel yang terdapat dalam penelitian ini seperti EWOM dan brand image, dimana hasil yang diperoleh setiap variabel positif dan signifikan, hal tersebut membuktikan bahwa konsumen memiliki niat untuk membeli, hal ini merupakan langkah selanjutnya bagi perusahaan Apple dalam meningkatkan inovasi produknya agar lebih banyak lagi konsumen yang ingin membeli produk Iphone, serta menjadi trendsetter bagi produk - produk smartphone dipasaran.

\section{SIMPULAN DAN SARAN}

Simpulan yang dapat diberikan berdasarkan hasil penelitian yang telah dilakukan yaitu EWOM berpengaruh positif dan signifikan terhadap brand image. Hasil penelitian ini menunjukkan bahwa semakin baik EWOM yang terjadi maka brand image dari produk Iphone juga akan semakin baik, dan sebaliknya apabila EWOM yang terjadi semakin buruk, maka brand image dari produk Iphone juga akan semakin buruk.

EWOM berpengaruh positif dan signifikan terhadap niat beli. Hasil penelitian ini menunjukkan bahwa semakin baik EWOM yang terjadi maka niat beli dari produk Iphone juga akan semakin meingkat, dan sebaliknya apabila EWOM yang terjadi semakin buruk, maka niat beli dari produk Iphone juga akan menurun. 
Rizky Darmawan, Peran Brand Image dalam Memediasi...

Brand Image berpengaruh positif dan signifikan terhadap niat beli. Hasil penelitian ini menunjukkan bahwa semakin baik brand image yang terjadi maka niat beli dari produk Iphone juga akan semakin meingkat, dan sebaliknya apabila brand image yang terjadi semakin buruk, maka niat beli dari produk Iphone juga akan menurun. Brand image memiliki peran dalam memediasi pengaruh EWOM terhadap niat beli produk Iphone. Hasil penelitian ini menunjukkan bahwa kekuatan brand image dari produk Iphone mempengaruhi dan menentukan efektivitas pengaruh dari EWOM terhadap niat beli produk Iphone.

Berdasarkan hasil dan kesimpulan dalam penelitian ini, maka saran yang diberikan yaitu perusahaan Apple Inc. sebagai produsen dari produk Iphone sebaiknya lebih memanfaatkan EWOM dalam memasarkan produknya, mengingat indikator terendah dari EWOM "Saya merasa tidak yakin dengan keputusan sendiri apabila tidak membaca ulasan produk Iphone dari sesama pengguna media internet." seharusnya promosi yang dilakukan pihak Apple Inc. lebih ditingkatkan lagi, dengan memanfaatkan media yang ada sekarang, seperti Internet ataupun media sosial sehingga mampu meningkatkan penjualan produk Iphone. Kemudian indikator "Saya merasa bahwa produk Iphone selalu melakukan inovasi terbaru" Merupakan indikator terendah dari brand image, maka sebaiknya pihak Apple Inc. lebih meningkatkan produknya dengan terus berinovasi mengikuti perkembangan jaman, agar mampu bersaing dengan produsen smartphone lainnya, serta meningkatkan minat beli konsumen terhadap produk Iphone. Selanjutnya indikator terendah dari niat beli yaitu "Saya berniat membeli produk Iphone dimasa yang akan datang karena produk Iphone melakukan inovasi yang 
berkelanjutan." hal ini menjadi pengingat bagi perusahaan Apple Inc. dikarenakan perusahaan Apple Inc. seharusnya memiliki trobosan - trobosan terbaru terhadap produknya, agar para konsumen tidak jenuh dengan produk - produk yang dibuat oleh perusahaan Apple Inc. salah satunya dengan memanfaatkan brand image yang kuat diharapkan mampu untuk menjadi strategi utama dalam meningkatkan penjualan dimasa yang akan datang.

Peneliti selanjutnya diharapkan mampu untuk menambah variabel dalam penelitian ini yang dapat mempengaruhi niat beli seperti kualitas produk, kualitas pelayanan ataupun yang lainnya, serta memperluas ruang lingkup wilayah penelitian dengan lebih banyak konsumen yang menggunakan produk Iphone.

\section{REFERENSI}

Aaker, David Allen. 2002. Building Strong Brands. London: The Bath Press

Aditya, Kadek Yoga dan Wardana, I Made. 2017. Peran Brand Equity dalam Memediasi Pengaruh Word Of Mouth terhadap Niat Beli. E-Jurnal Manajemen Unud. 6 (2). Hal. 830 - 856

Ambarwati, Miki; Sunarti dan Mawardi, Mukhammad Kholid. 2015. Pengaruh Citra Merek terhadap Minat Beli (Survei Pada Mahasiswa Universitas Brawijaya yang Menggunakan Pasta Gigi Pepsodent). Jurnal Administrasi Bisnis. 25 (1). Hal. $1-7$

Bataineh, Abdallah Q. 2015. The Impact of Perceived e-WOM on Purchase Intention: The Mediating Role of Corporate Image. International Journal of Marketing Studies. 7 (1). PP. 126 - 137

Bambauer Sachse, Salke and Mangold, Sabrina. 2011. Brand Equity Dilution Through Negative Online Word-of-Mouth Communication. Journal of Retailing and Consumer Services. 18. PP. $38-45$

Chao, Reng Feng and Liao, Ping Chu. 2016. The Impact of Brand Image and Discounted Price on Purchase Intention in Outlet Mall: Consumer Attitude 
Rizky Darmawan, Peran Brand Image dalam Memediasi...

as Mediator. The Journal of Global Business Management. 12 (2). PP. 119 128

Charo, Naimatullah; Sharma, Pershant; Shaikh, Saadullah; Haseeb, Abdul and Sufya, Muhammad Zohaib. 2015. Determining The Impact of E-wom on Brand Image and Purchase Intention Through Adoption of Online Opinions. International Journal of Humanities and Management Sciences. 3 (1). PP. $41-46$

Dewa, Chriswardana Bayu. 2015. Pengaruh Country of Origin Produk Televisi LG Terhadap Niat Beli Konsumen dengan Ekuitas Merek Sebagai Variabel Pemediasi. Jurnal Bianglala Informatika. 3 (1). Hal. 74 - 82

Dwi Putranti, Honorata Ratnawati dan Pradana, Denny FX. Electronic Word of Mouth (E-WOM), Kepuasan Konsumen dan Pengaruh Langsung dan Tak Langsung Terhadap Minat Beli Konsumen (Studi Pada Mahasiswa FEB UNTAG di Semarang). Media Ekonomi dan Manajemen. 30 (1). Hal. 101 113

Elseidi, Reham I and El Baz, Dina. 2016. Electronic Word of Mouth Effects on Consumers' Brand Attitudes, Brand Image and Purchase Intention: an Empirical Study in Egypt. The Business and Management Review. 7 (5). PP. $268-276$

Heruwati, Eni. 2010. Pengaruh Kredibilitas, Daya Tarik, dan Keahlian Celebrity Endorser terhadap Keputusan Pembelian Sepeda Motor Yamaha Mio. Skripsi Fakultas Ekonomi Universitas Diponegoro. Semarang.

Hyun, Sunghyup Sean and Kim, Wansoo. 2011. Dimensions of Brand Equity in the Chain Restaurant Industry. Cornell Hospitality Quarterly. 52 (4). PP. $429-437$

Jaafar, Siti Nurafifah; Lalp, Pan Ein and Naba, Mohaini Mohamed. 2013. Consumers Perceptions, Attitudes and Purchase Intention Towards Private Label Food Products in Malaysia. Asian Journal of Business and Management Sciences. 2 (8). PP. 73 - 90

Jalilvand, Mohammad Reza and Samiei, Neda. 2012. The Effect of Electronic Word of Mouth on Brand Image and Purchase Intention an Empirical Study in The Automobile Industry in Iran. Marketing Intelligence and Planning. 30 (4). PP. 460 - 476

Kartika, Cherry dan Piranti, Dwi. 2015. Pengaruh EWOM (EWOM) Twitter @ batikair Terhadap Brand Image. Jurnal Visi Komunikasi. 14 (1). Hal 104 $-116$ 
Kementerian Komunikasi dan Informatika. Empat (4) Negara Dengan Pengguna Internet Tertinggi. https://www.kominfo.go.id/ (diunduh tanggal 30 Januari 2018)

Lin, Chinho; Wu, Yi Shuang and Victor Chen, Jeng Chun. 2013. Electronic Word-of-Mouth: The Moderating Roles of Product Involvement and Brand Image. International Conference on Technology Innovation and Industrial Management. Phuket, Thailand. PP. $29-47$

LoveLock, Christoper; Wirtz, Jochen and Mussry, Jacky. 2010. Pemasaran Jasa : Manusia, Teknologi, Strategi. Edisi ke 7. Jakarta : Erlangga.

Moksaoka, I Made Weli. dan Rahyuda, Ketut. 2016. Peran Brand Image dalam Memediasi Country of Origin Terhadap Purchase Intention. E-Jurnal Manajemen Unud. 5 (3). Hal. 1690 - 1716

Mowen, John C. and Minor, Michael. 2007. Perilaku Konsumen. Edisi Kedelapan. Jilid 1. Jakarta: PT Gramedia Erlangga.

Priyanto, Dwi. 2008. Mandiri Belajar SPSS. Yogyakarta: Meiako.

Rahyuda, Ketut. 2004. Buku Ajar Metodelogi Penelitian. Denpasar: Fakultas Ekonomi Universitas Udayana.

Riduwan \& Kuncoro. 2011. Cara Menggunakan dan Memakai Path Analysis (Analisis Jalur). Bandung : Alfabeta.

Rangkuti, F. 2002. Measuring Customer Satisfaction Teknik Mengukur dan Strategi Meningkatkan Kepuasan Pelanggan dan Analisis Kasus PLN-JP. PT. Gramedia Pustaka Utama, Jakarta

Sa'ait, Noraini; Kanyan, Agnes and Nazrin, Mohamad Fitri. 2016. The Effect of $\mathrm{E}-\mathrm{WOM}$ on Customer Purchase Intention. International Academic Research Journal of Social Science. 2 (1). PP. 73 - 80

Semuel, Hatane dan Lianto, Adi Suryanata. 2014. Analisis e-WOM, Brand Image, Brand Trust dan Minat Beli Produk Smartphone di Surabaya. Jurnal Manajemen Pemasaran. 8 (2). Hal 47 - 54

Setiawan, Putu Yudi; Troena, Eka Afnan; Armanu and Noermijati. 2014. The Effect of e-WOM on Destination Image, Satisfaction and Loyalty. International Journal of Business and Management Invention. 3 (1). PP. 22 $-29$ 
Shahrinaz, Irwan; Kusuma, Jati; Yacob, Yusman; Abdul Rahman, Dayang Hummida Abang and Mahdi, Ahmad Faisal. 2016. Relationship and Impact of E-WOM and Brand Image Towards Purchase Intention of Smartphone. Journal of Scientific Research and Development. 3 (5). PP. 117 - 124

Shimp, Terence. A. 2010. Integrated marketing communications in advertising and promo-tions. Eight edition. South-Western: Cengage Learning.

Sugiyono. 2013. Metode Penelitian Bisnis. Cetakan ke 17. Bandung: CV Alfabeta.

Sutisna. 2001. Perilaku Konsumen dan Komunikasi Pemasaran. Bandung: PT. Remaja Rosdakarya.

Sweeney, Jill; Soutar, Geoff and Mazzarol, Tim. 2014. Factors Enchancing Word of Mouth Influence : Positive and Negative Service Related Messages. European Journal of Marketing. 48 (1/2). PP. 336 - 359

Torlak, Omer; Ozkara, Behcet Yalin; Tiltay, Muhammet Ali; Cengiz Hakan and Dulger, Mehmet Fatih. 2014. The Effect of Electronic Word of Mouth on Brand Image and Purchase Intention: an Application Concerning Cell Phone Brands for Youth Consumers in Turkey. Journal of Marketing Development and Competitiveness. 8 (2). PP. $61-68$

Wibowo, Arif. 2015. Pengaruh Elektronik Word Of Mouth dan Brand Image terhadap Purchase Intention pada Konsumen Smartphone Samsung yang Berbasis Android. Jurnal Ilmu Manajemen. 12 (1). Hal. 71 - 88

Wijaya, Finna Anastasia dan Sugiharto, Sugiono. 2015. Pengaruh Elektronik Word of Mouth dan Brand Image terhadap Purchase Intention pada Konsumen Smartphone Samsung yang Berbasis Android. Jurnal Manajemen Pemasaran. 9 (1). Hal. 16 - 22

http://www.kominfo.go.id/2017/11/Empat-Negara-Dengan-Pengguna-InternetTertinggi. Diakses pada tanggal 27 November 2017 